\title{
Women's Career Strategy Choices and Fertility in Finland
}

\author{
ELINA SCHLEUTKER, Department of Political Science, University of Freiburg, \\ Germany
}

\section{Abstract}

To better understand the correlation between fertility, female employment, and family policy, this paper employs Finnish register data on women born in 1969 to study the association between women's labour market careers and fertility. The investigation is based on a theoretical argument which holds that women make different kinds of strategic choices about their careers as influenced by their own preferences, family policies, and household resources. Women are divided into three different groups based on their activity in the labour market from the month they reach age 18 until the month before they turn 35. The level and timing of fertility, the central characteristics of the women belonging to the different groups, and the entry into motherhood are examined with descriptive statistics and event history techniques. Results show that Finnish women's choices concerning employment and fertility are relatively heterogeneous: At one end of the scale a considerable number of women stay outside the labour market for longer periods of time, enter motherhood at a relatively early age, and have large families, whereas at the other end we find women with long periods of continuous education and employment, high age of entry into motherhood, and small family sizes.

Key words: fertility, preference theory, family policy

\section{Introduction}

The determinants of fertility decline, low fertility, and fertility differences within and between countries are frequently discussed by demographers. Different scholars approach these topics from different theoretical perspectives, varying from economic considerations (Becker 1981/1991) to frameworks which emphasize for example the role of values (van de Kaa 2001) or timing of births (Sobotka 2004). During the past two decades, family policy, insofar it influences gender equity (McDonald 2000a, 2000b, 2002) and the compatibility between maternal and worker roles (Brewster and Rindfuss 2000; Rindfuss and Brewster 1996; Rindfuss, Guzzo and Morgan 2003) has increasingly received attention from demographers. It is argued that when family policy enables the combination of work and family, both fertility and female employment are positively influenced, given that women do not need to choose between employment and children but can have both. Such arguments have been challenged by Hakim $(1998,2000,2002,2003 a, 2003 b)$, who claims that women are heterogeneous in 
their preferences when it comes to family and work, and thus respond differently to social policy. In addition, Hakim claims that preferences are increasingly important determinants of behaviour, and has therefore been criticized for underestimating the role of different constraints related to e.g. family policy, financial situation, and attitudes (e.g. Kan 2007; Kangas and Rostgaard 2007). At the same time, the research on fertility ideals (Goldstein, Lutz and Testa 2003; Heiland, Prskawetz and Sanderson 2008), employment preferences (Janus 2012; Vitali et al. 2009), fertility outcomes (Frejka 2008), and women's labour market participation (Lewis, Campbell and Huerta 2008) shows that women are heterogeneous in their desires and choices. Thus, even though it is not clear how and to which extent preferences and constraints influence women's choices, previous research suggests that it is important to not treat women as one homogeneous group, but to investigate the heterogeneity in more detail.

Elsewhere I have discussed the relationship between women's preferences and choices (Schleutker, in press) and suggested that women have, as argued by Hakim, heterogeneous preferences which eventually lead to choices about what Bernhardt $(2000,10)$ has called different "lifetime career strategies in relation to childbearing". I further proposed that the influence of preferences on actual work-life decisions is conditional to family policy and household's own resources. These assumptions lay the theoretical ground for the current paper, and will be discussed in detail below. As the causal chain from preferences to behaviour, and the influence of family policy and household's own resources on women's choices cannot be studied due to the lack of appropriate data, the empirical part of the paper consists of a study on women's labour market participation and fertility in Finland, and relies on Finnish register data for the 1969 cohort (Statistics Finland 2011). The purpose of this article is to provide descriptive evidence on the proportion of women opting for different types of career strategies, the level and timing of fertility in each of the career strategy groups, and the typical characteristics of the women belonging to each group. Moreover, event history regression is employed for descriptive purposes in order to examine the relationship between women's typical characteristics and entry into motherhood within each group.

The article is organized as follows: In the next section, some background information on fertility, family formation, and female labour force participation in Finland is given. Thereafter the theoretical framework of the study is outlined, and previous research focusing on Finland is reviewed in the light of the theory. Presentation of the method and material of the study is followed by an account of the results and finally, discussion.

\section{Background: Family formation, fertility, and female employment}

This section will examine the general trends in family formation, fertility, and female labour force participation in Finland. For a more in depth review of Finnish fertility trends, Vikat (2002), Ruokolainen and Notkola (2007), as well as Andersson et 
al. (2009) are recommended. Pitkänen and Jalovaara (2007) provide an informative summary of the trends in family formation and a detailed overview of female labour force participation can be found in Haataja (2005).

Table 1. Indicators of family formation, 1965-2010.

\begin{tabular}{ccccccc}
\hline Cohabitation $^{1}$ & $\begin{array}{c}\text { Proportion } \\
\text { of live births } \\
\text { outside } \\
\text { marriage }\end{array}$ & $\begin{array}{c}\text { Crude } \\
\text { marriage rate }\end{array}$ & $\begin{array}{c}\text { Median } \\
\text { age at first } \\
\text { marriage, } \\
\text { women }\end{array}$ & $\begin{array}{c}\text { Crude } \\
\text { divorce rate }\end{array}$ & $\begin{array}{c}\text { Reconstituted } \\
\text { families as a } \\
\text { proportion of } \\
\text { families with } \\
\text { children, \% }\end{array}$ \\
$\mathbf{1 9 6 5}$ & & 4.6 & 7.9 & 22.3 & 1.0 & \\
$\mathbf{1 9 7 5}$ & 10.2 & 6.7 & 22.7 & 2.0 & \\
$\mathbf{1 9 8 5}$ & 12.8 & 16.4 & 5.3 & 24.2 & 1.8 & \\
$\mathbf{1 9 9 5}$ & 21.0 & 33.1 & 4.7 & 26.3 & 2.7 & 6.6 \\
$\mathbf{2 0 0 0}$ & 24.8 & 39.2 & 5.1 & 27.1 & 2.7 & 7.7 \\
$\mathbf{2 0 0 5}$ & 27.4 & 40.4 & 5.6 & 27.8 & 2.6 & 8.8 \\
$\mathbf{2 0 1 0}$ & 28.7 & 41.1 & 5.6 & 28.6 & 2.5 & 9.1 \\
\hline
\end{tabular}

Notes: ${ }^{1}$ Refers to cohabiting persons aged $15-64$ as a percentage of all persons living in a union. Data for 2010 is for 2009. ${ }^{2}$ Data for $1965-2005$ refers to five-year averages, and data for 2010 is from 2009.

Sources: Columns 1 and 4: Miettinen (2011:166). Columns 2, 3 and 5: Eurostat (2013). Column 6: Statistics Finland (2013).

For family formation (Table 1), the trends in Finland are typical for a country experiencing the second demographic transition (van de Kaa 1987). In 1985, for instance, $12.8 \%$ of all people living in a union were cohabiting, but in 2010 this percentage had increased to $28.7 \%$. Simultaneously to the cohabitation increase, the number of extramarital births grew, the median age at first marriage increased, the propensity to marry decreased, and the propensity to divorce increased. In 1965 , only $4.6 \%$ of children were born outside of marriage, but in 2010 as many as $41.1 \%$ of newborn children were extramarital. The crude marriage rate, in turn, decreased from 7.9 in 1965 to 5.6 in 2010, while during the same period the median age of women at first marriage increased from 22.3 to 28.6 years of age. As for the propensity of divorce, the crude divorce rate increased from 1.0 to 2.5 during 1965-2010. Despite the increase in divorces, reconstituted families, that is, families where children are not biologically related to both parents, are not very common in Finland: In 2010 only $9.1 \%$ of all families with children were reconstituted.

The changes in family formation were at first accompanied by substantial declines in fertility, but after the total fertility rate (TFR) reached its all-time low (1.49) in 1973, the fertility rate has fluctuated between $1.59-1.87$. The cohort fertility rates by age 40 (CFR-40) in turn have been in general higher, above 1.8 children per woman for 
the 1924-1969 cohorts. As to the timing of the births, the period mean age at birth (MAB) declined at first together with the TFR during 1960-1972, but has thereafter continuously increased from 26.8 in 1972 to 30.3 in 2011 (Figure 1).

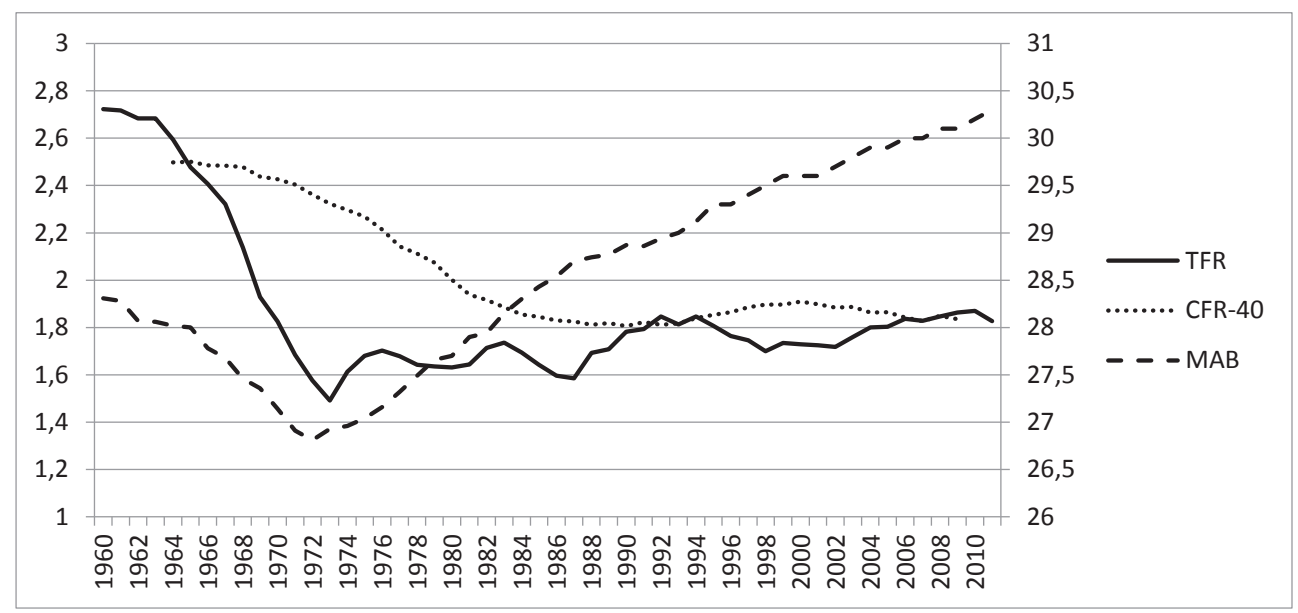

Figure 1. The TFR and MAB (years 1960-2011) and CFR-40 (cohorts 1924-1969) Sources: For TFR and MAB, Eurostat (2013). For CFR-40, Human Fertility Database (2012).

Female labour force participation (FLFP) in Finland has traditionally been high; already in 1963 as many as $67.4 \%$ of women aged $25-54$ were working outside the home. A substantial increase took place in the 1960s-1980s, but during the past two decades the FLFP of Finnish women has been relatively stable, approximately $84-85 \%$. The share of part-time working women has likewise been relatively stable and low, and the share of part-time work (of total employment) is now $10.1 \%$ in comparison to $8.1 \%$ in 1989 . These seemingly steady trends over the past two decades hide the radical increases in unemployment during the recession at the beginning of the 1990s, when female unemployment rapidly increased and finally peaked at $13 \%$ in 1995 . Moreover, despite the high FLFP, women in childbearing age still have considerably lower employment rates than men: The gap between female and male participation rates at ages 25-34 has consistently been above 10 percentage points during the past two decades (see Figure 2). 


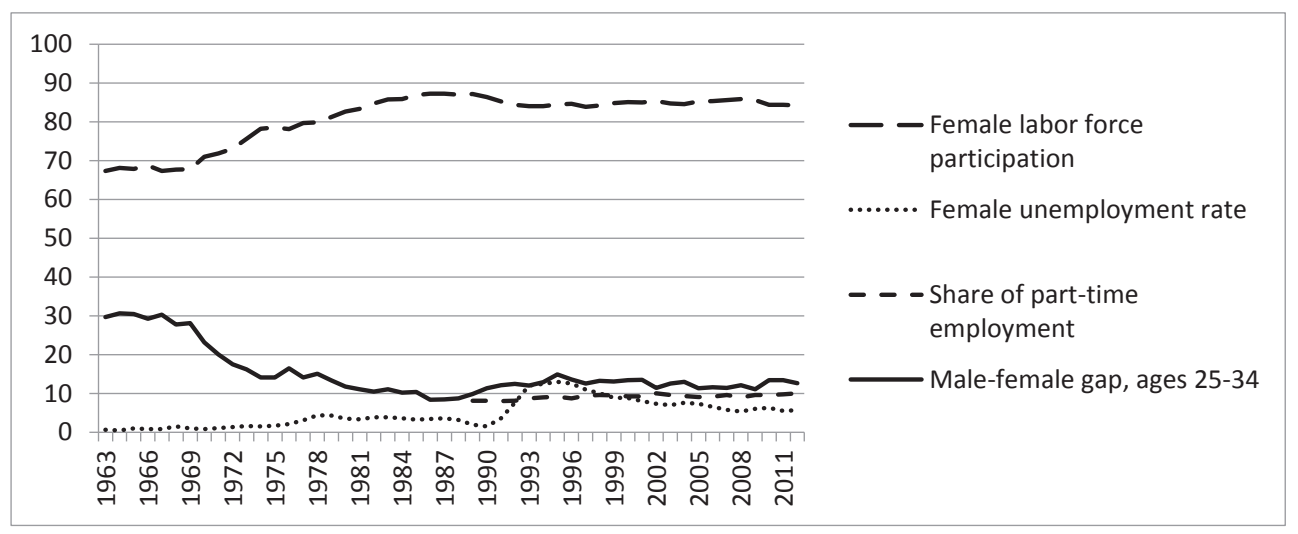

Figure 2. Labour market indicators, 1963-2012.

Source: OECD (2013).

Notes: Data on female labour force participation, unemployment rate and part-time employment is for age group 25-54.

\section{From heterogeneous preferences to heterogeneous choices}

It is often argued that the high fertility and female employment in Finland (and other Nordic countries) can be explained by the women-friendly family policy, which facilitates home/work role compatibility. However, elsewhere I have claimed that it is important to give more attention to the heterogeneity in women's preferences and behaviour (Schleutker, in press). As my previous work lays the groundwork to the empirical analysis below, I will first briefly review my argument, and discuss the Finnish case in the light of the theory.

\section{Women's heterogeneous preferences and career choices}

According to Hakim (1998, 2000, 2002, 2003a, 2003b), preferences have increasing influence on the choices women make. Moreover, she argues that women have heterogeneous preferences and that due to their preferences, women respond differently to government-implemented social policies. She further divides women into three different groups based on their life style preferences: Home-centered women who prefer homemaking, work-centered women whose first priority is their job, and adaptive women who do not have strong preferences for either homemaking or employment, but wish to have both. Previous research on women's preferences supports the heterogeneity assumption (Janus 2012; Vitali et al. 2009). In Finland, when children are under six years of age, $80.3 \%$ of couples find the full-time dual earner model to be the best option, and $8.6 \%$ of the couples prefer that the man works full-time and the woman part-time. Likewise, preference for sole earner families is relatively low at 10.2\% (OECD 2001, 136). The results from the International Social Survey Programme (ISSP) 2002 show that $13 \%$ of the Finnish mothers think that a mother with children under school age should be working full-time, whereas $44 \%$ of the mothers found part-time work, and 
$43 \%$ found homemaking to be the best work-life solution for mothers with children under school age (Hakovirta and Salin 2006). Also employing ISSP 2002 data, Janus (2012) concludes that $15 \%$ of all Finnish women are work-centered, $77 \%$ adaptive and $7 \%$ home-centered. Among the partnered mothers with school-aged children, the share of work-centered and home-centered women was slightly lower. The variation in the estimates of women's preferences between these two studies which use the same data can be explained by the differences in the study designs. Hakovirta and Salin (2006) include only those women aged 18-49 who lived in the same household with at least one under 18-year old child, whereas Janus (2012) studies all female respondents.

We also know that Finnish women are heterogeneous in their choices. For example, as many as $38.5 \%$ of Finnish couples with children aged $0-2$ follow the full-time dual earner model, $45.8 \%$ in turn follow the single breadwinner model, and in $9.3 \%$ of the couples one parent works full-time and the other part-time. When children are school age, the share of full-time dual earner couples increases to $72.8 \%$ and the single breadwinner couples declines to $13.7 \%$, whereas the share of part-time/full-time earner couples remains the same (Table 2). Thus, although the polarization of the couples is largest when the children are young, there are many differences even as the children grow older.

The results from the above studies show that there is a gap between preferences and behaviour. For example, Hakovirta and Salin $(2006,264)$ conclude that only $59 \%$ of the mothers who wanted to stay at home actually realized this choice, whereas $28 \%$ were working full-time, and $13 \%$ were working part-time. Further, of mothers with part-time preference $53 \%$ were against their wishes in full-time employment and $22 \%$ were at home, which means that only $25 \%$ of the women worked part-time. The situation was best for those women who preferred full-time work, as $91 \%$ of them were working full-time and $9 \%$ were at home. In other words, preferences alone do not explain behaviour, but it is likely that some factors constrain women's possibilities to choose according to their preferences.

Table 2. Employment patterns among couple families by age of youngest child (\%), 2008.

\begin{tabular}{rccccc}
\hline Age & $\begin{array}{c}\text { Both } \\
\text { parents } \\
\text { full-time }\end{array}$ & $\begin{array}{c}\text { One } \\
\text { parent } \\
\text { full-time }\end{array}$ & $\begin{array}{c}\text { One } \\
\text { parent } \\
\text { full-time, } \\
\text { one parent } \\
\text { part-time }\end{array}$ & $\begin{array}{c}\text { Neither } \\
\text { parent in } \\
\text { employment }\end{array}$ & Other \\
$\mathbf{0 - 2}$ & 38,5 & 45,8 & 9,3 & 4,0 & 2,4 \\
$\mathbf{3 - 5}$ & 62,8 & 18,9 & 11,6 & 2,5 & 4,2 \\
$\mathbf{6 - 1 4}$ & 72,8 & 13,7 & 9,3 & 2,5 & 1,8 \\
\hline
\end{tabular}

Source: OECD (2012). 
To explain why and in which ways heterogeneity in preferences leads to heterogeneity in behaviour, we can draw from Bernhardt $(2000,10)$ who suggests that women realize three different types of "lifetime career strategies in relation to childbearing": Career strategy, combination strategy and homemaking strategy. As the labels indicate, careerists concentrate on their career, combiners combine work and family, and homemakers stay at home with their children. It follows, then, that we can assume home-centered women prefer homemaking, adaptive women prefer the combination strategy, and work-centered women prefer the career strategy.

\section{Preferences, family policies, and household's resources as determinants of career strategies}

In order to understand women's career strategy choices it is, in addition to preferences, important to concentrate on family policy and household's own resources (i.e. financial assets, family members and relatives who participate in childcare), as these factors are well known to influence the choices women make (for family policy, see e.g. Esping-Andersen 1999; for financial assets, see e.g. Becker 1981/1991; for family members and relatives who participate in childcare, see e.g. Cooke 2004; Torr and Short 2004). In an international comparison of family policy, Finland together with other Nordic countries is often classified as a family friendly welfare state where the combination of work and family is supported by individual taxation, generous leave arrangements, and good availability of child care (Esping-Andersen 1999; Thévenon 2011). In particular, the Finnish family policy is organized around the principle of the parents' right to choose between home care and institutional care: After the relatively long maternity and parental leaves (approximately four and six months respectively) which are generously compensated (either with a wage-dependent amount or flat-rate compensation), one of the parents has the right to stay at home on care leave to take care of the child(ren) until the youngest child turns into three. At the same time, municipalities must organize day care for those families who require it.

The basic home care allowance (HCA) is a flat-rate compensation, but the size of the total HCA depends on the number of siblings (sibling-bonus) and income (low income families receive an additional payment). In addition, some municipalities pay the socalled municipal home care allowance for those families who do not use the day care services provided. The HCA was particularly generous during the recession years in the beginning of the 1990s, when it was possible to receive an HCA in addition to unemployment benefits (Anttonen 2003; Haataja 2007; Miettunen 2008; Välimäki and Rauhala 2000). In other words, the incentives for women spending longer periods outside the labour market were considerable, especially for those mothers who had lost their jobs due to the recession. During 1991-1993, the net HCA was between 25-29\% of the disposable income of one-earner family with two children, but declined to $17 \%$ in 1996 when substantial cuts were made to the program (Hiilamo 2000). 
On the other hand, the HCA alone is not high enough to compensate for the costs of homemaking, which means that lone mothers and mothers with low-earning partners might not be able to choose their home-centered preferences with the help of the HCA. Additionally, financial support for home care is restricted to families whose youngest child is aged $0-2$, which means that the freedom of choice is limited only to parents whose youngest child is under three years of age. The tax system namely also supports dual earner families: The tax rates are high (Kurjenoja 2003), since 1976 individual taxation of a couple's income is applied, and the deductions based on children or a spouse were conclusively abolished in 1994 (Haataja and Pylkkänen 2009).

The care leave is highly popular among parents (Salmi and Lammi-Taskula 2002) and the take-up rates have consequently been high: Between 1996 and 2006 the HCA was paid for $51-56 \%$ of all children under three years of age (Miettunen 2008, 28). The enrollment rates in publicly provided day care reflect the popularity of the care leave. In 1995 only $18 \%$ of the children under age of three were enrolled in formal child care, and in 2008 the share was $28.3 \%$ (OECD 2012).

Finally, previous research shows that there is a correlation between household's resources and the choices women make. For example, mothers who already had a work place before the child birth were more likely to return to the labour market instead of taking care leave (Lammi-Taskula 2004). Likewise, mothers with higher education and income are likely to return to the labour market more frequently and more rapidly in comparison to mothers with lower education or income (Haataja 2005; Salmi, Lammi-Taskula and Närvi 2009; Takala 2000). The negative effect of the municipal HCA-supplements on mothers' labour force participation is stronger among the highly educated women (Kosonen 2011). Further, fathers appear to have a role in facilitating the combination and career strategies: Fathers whose spouse has a good position in the labour market (Lammi-Taskula 2008) or fathers with highly educated spouses (Hämäläinen and Takala 2007; Takala 2005) were more likely to take parental leave. However, most likely due to the high availability of publicly provided childcare, the role of informal care is rather minimal in Finland: Only 2\% of children under school age are primarily taken care of by a relative other than the mother or the father (Takala 2000, 48).

\section{Method and material \\ Data}

Data used in this study comes from the Finnish Palapeli, which is a longitudinal dataset on couples, children, families, and living conditions from different administrative registers. All individuals who have received a personal identification number are included in the dataset. For the purposes of this investigation, Statistics Finland (2011) provided a 90\% extract of the women born in January 1969. For these women, data on various indicators were provided for the years 1987-2003 (that is, from the 
month the individuals reached the age of $18=1 / 1987$ until the last month of their $35^{\text {th }}$ living year $=12 / 2003$ ). The fertility data included births that occurred before the $18^{\text {th }}$ birthday. Some women were excluded from the study as they had adopted children, experienced a registered stillbirth or multiple births, or when there were inconsistencies in the date of childbearing. In addition, in order for the dataset to reflect only those women who have resided during the entire observation period in Finland, all women for whom information on the combined indicator of "months in employment and unemployment" was missing were excluded from the analysis. The original extract included 2696 women, after exclusions 2243 women remained. Given the nature of the exclusions, the data used in this study is highly representative of Finnish women belonging to the 1969-cohort.

\section{Classification of women into career strategy groups}

The classification of the women into the three career strategy categories is based on information about their employment activity from January 1987, the month they reached age 18, until the last month of their $35^{\text {th }}$ year, December 2003. The data employed in this study contains information on (1) the number of months per year a woman spent in employment and unemployment, (2) the number of months a year she spent in unemployment (3) and the approximate date (year and month) she received her highest educational degree. There is also information on (4) her main type of activity during the last week of the year. These employment indicators are reliable, but there are nevertheless some drawbacks: Firstly, it is impossible to distinguish between full-time and part-time work. Secondly, over the years there have been some changes in the way in which the number of months of unemployment have been calculated. Thirdly, for some women in some years, the number of months in employment and unemployment equal zero, even though they were employed during the last week of the year and their taxable income was very high. Fourthly, in an ideal case women in parenting leave would be counted as inactive. In the data this condition is met for women taking care leave, who in the monthly data are in general counted as neither employed nor unemployed, and the main type of activity during the last week of the year for these women is simply "other outside the labour force". However, both in the monthly and yearly data women in maternity/parental leave are in general counted as employed if they had an employment contract before requesting leave. Finally, there is no information on the start date of education, nor on actual time spent in education.

The women were classified into three different groups in several steps. In the first step, the number of months in employment was calculated (by subtracting the number of months in unemployment from the combined indicator of number of months in employment and unemployment). The assumption made in step two was that when the activity listed for the last week of the year was "employed" or "in education", and the highest education level was attained after the year in question, the woman had been in education during the whole year (in the register those women who are working 
concurrently with their studies are classified as employed rather than as students). This assumption was necessary as there are, for example, women whose highest degree attained at age 30+ was a high school degree, and it would be unreasonable to assume that these women had been studying full-time since the age of 18 . During the year the highest education level was attained, the number of months in education was assumed to end in the month the degree was attained. In the next step, I assumed that those women for whom there are no recorded months of employment, unemployment, or in education had nevertheless been active during the whole year if their activity at the end of the year was listed as "employed" or "in education".

As the classification follows the previously explained theory, and as the study is explorative in its nature, it makes sense to draw coarse limits to see whether the theoretical arguments have any real-world relevance, that is, to see if it is possible to distinguish between different groups of women who differ substantially from each other and if the groups are large enough to be considered as important. The classification of the women into the different groups was made as follows: (1) Women who have been unemployed or inactive for a total of six years or more are classified as homemakers (that is, women who have not been employed or enrolled in education for at least six complete years). (2) Women who have been studying and/or working continuously during at least 16 years of the observation period are classified as careerists. (3) All women who have not been classified as homemakers or careerists are assumed to be combiners. This group consists of women who during at least 13 months have been unemployed or outside the labour market.

Even though the dataset comprises information on the country of birth, I made the decision to analyze native and immigrant women together. I did not consider a separation important, given that only $1.3 \%$ of the women included in the analysis were foreign-born, the women came to Finland at a relatively early age which is known to increase the adaptation to local fertility patterns (Andersson 2004), and these women were evenly distributed between the different career strategy groups (i.e., approximately $1.2-1.3 \%$ of the women in each group were foreign-born).

\section{Variables}

The variable education includes information on the highest educational attainment. Five categories can be distinguished: Low education (compulsory education only), general education, upper secondary level (high school with theoretical emphasis), upper secondary level (vocational school), lowest level tertiary education (practically oriented education) and college (university, university of applied sciences). For income the dataset includes yearly information on taxable income, HCA, maternal/parental benefits, and unemployment benefits. Following Vikat (2004), all benefits were subtracted from taxable income to approximate the earnings of women. Using the consumer price index, all values were transformed into 2003 values, and a division of women into different income groups was made as follows: women with an income below $14000 \mathrm{e} /$ 
year were classified as having low income, women with income between 14 100e-24 $400 \mathrm{e}$ were classified as having medium income and women with income higher than $24500 \mathrm{e}$ were classified as having high income. For main type of activity and family status information is gathered yearly at the end of the year. The categories for the activity status are as follows: "Employed", "unemployed", "in education", "pensioner", and "other outside the labour force". The category "other outside the labour force" comprises all women whose activity status was either none of the previously listed or unknown (these women can be for example on care leave, on maternity leave without an employment contract, or unemployed without receiving unemployment benefits). The categories for family status are: "No family", "married, no children", "married with children", "lone mother", "cohabiting couple with common children", "cohabiting couple with no common children" and "cohabiting couple without children".

\section{Statistical Method: Cox proportional hazards model}

Cox proportional hazards model is applied for descriptive purposes to study the entry into motherhood. In other words, the aim of the regression is not to make strong claims about the causal associations between the different variables, but to conduct a preliminary explorative analysis. On the one hand, it is interesting to study whether the independent variables are differently related to the transition rates among the women belonging to different groups. If we assume that women in the different groups are selected partly based on their preferences, it is reasonable to assume different responses to different variables. On the other hand, it is interesting to see how homogeneous the group of women who have chosen the same career strategy are concerning the determinants of their choices.

As many of the variables do not necessarily satisfy the proportionality assumption (that the influence of a certain variable, for example education, is the same during the entire observation period), the results of the analysis should be interpreted as averages over time (Box-Steffensmeier, Reiter and Zorn 2003). The process time is the elapsed time from the month the individual reached the age of 15 . Women are right-censored when they reach the age of 35 . All variables were included as time constant, except for income and activity status, which were included as time-varying. The women were assumed to be in education and without income before they reached their $18^{\text {th }}$ birthday. Thereafter, the income and activity status of the year $t$ is introduced as an independent variable for the possible births occurring in year $\mathrm{t}+1$.

\section{Empirical findings}

As can be seen in Table 3, as many as $28 \%$ of the Finnish women are homemakers, $50 \%$ are combiners, and $21 \%$ are careerists. As the current data does not properly take part-time work and the months in maternal/parental leave into consideration, it is likely that some women who in reality have been working part-time or who have 
been in parental leave several times are now classified as careerists. In other words, the actual share of the careerists is likely to be smaller and the share of the combiners larger. The observed polarization was to be expected based on the theory, but the high share of the homemakers is rather surprising. One possible explanation of the finding is that especially young women with low education suffered from unemployment due to the recession in the beginning of the 1990s (Myrskylä 2010), which might have influenced even their long-term labour market careers.

Table 3. Life time career strategies of the Finnish women in the 1969-cohort.

\begin{tabular}{lcccc}
\hline & All women & Homemakers & Combiners & Careerists \\
Share of the population, \% & 100 & 28 & 50 & 21 \\
\hline
\end{tabular}

\section{Level and timing of fertility}

Average fertility (Table 4) for homemakers is 1.99 children, which means that homemakers are the only group able to almost reproduce itself by age 35 . For careerists, the average fertility is substantially lower at 1.05 , almost half of the homemakers' fertility. The combiners, in turn, experience average fertility of 1.56 , which is approximately the same as the average fertility for all women, 1.58. As to family size, the level of childlessness is lowest among the homemakers $(20 \%)$ followed by the combiners $(25 \%)$ and the careerists $(43 \%)$. The level of childlessness among homemakers is surprisingly high and calls for further investigation. Of the childless homemakers, approximately $30 \%$ had at least once been registered as "pensioner" in the end of the year and $70 \%$ of the childless homemakers had been registered as either "unemployed" or "pensioner" at least six times in the activity designation at the end of the year. The pensioner-status indicates physical or psychological problems, which in turn might mean that these women are not willing or able to have children. Likewise, women who experience unemployment might not feel economically secure enough to have children. In any case, the large share of childless homemakers suggests that long-term unemployment and being a pensioner is strongly correlated with childlessness. This result is consistent with Vikat's (2004) study, where an extract of the same dataset was employed.

Table 4. Share of women at different parities (\%) and average fertility.

\begin{tabular}{|c|c|c|c|c|}
\hline & $\begin{array}{c}\text { All } \\
\text { women }\end{array}$ & $\begin{array}{l}\text { Home- } \\
\text { makers }\end{array}$ & Combiners & Careerists \\
\hline \multicolumn{5}{|c|}{ Share of women at different parities, $\%$} \\
\hline 0 & 27 & 20 & 25 & 43 \\
\hline 1 & 18 & 15 & 18 & 19 \\
\hline 2 & 35 & 32 & 38 & 29 \\
\hline 3 & 14 & 19 & 14 & 8 \\
\hline $4+$ & 6 & 14 & 4 & 1 \\
\hline Average fertility & 1.58 & 1.99 & 1.56 & 1.05 \\
\hline
\end{tabular}


The homemakers have the largest families and the careerists the smallest. The share of women at first parity varies from $15 \%$ among the homemakers to $18 \%$ among the combiners and $19 \%$ among the careerists. The share of women at second parity, in turn, is $32 \%$ among the homemakers, $38 \%$ among the combiners, and $29 \%$ among the careerists. The differences between the groups become more pronounced at higher parities: $19 \%$ of the homemakers, $14 \%$ of the combiners, and $8 \%$ of the careerists were at third parity and $14 \%$ of the homemakers, $4 \%$ of the combiners, and $1 \%$ of the careerists at fourth-or-higher parity. The case of the homemakers thus demonstrates that despite the high share of childlessness it is possible to reach replacement fertility as many women progress to higher parities.

In Table 5 the contribution of the different groups to fertility is shown. The contribution of the homemakers increases with parity: $20 \%$ of all childless women are homemakers, whereas as many as $63 \%$ of the women at fourth-or-higher parity are homemakers. This means that the homemakers contribute $36 \%$ to the total fertility (i.e., $36 \%$ of all births occurred to homemakers) which is somewhat more than their total share of the population. For combiners the contribution is more in balance with their share of the population (a noteworthy exception is that the combiners contribute only $35 \%$ to the total share of the women at fourth-or-higher parity). Finally, the contribution of the careerists decreases with parity: Of all childless women 33\% are careerists but only $3 \%$ of all women at fourth-or-higher parities are careerists. All in all, the careerists contribute with $14 \%$ to the total average fertility, which is somewhat less than their total share of the population.

Table 5. Contribution to average fertility and to fertility at different parities, \%.

\begin{tabular}{lcccc}
\hline Contribution at each parity & $\begin{array}{c}\text { All } \\
\text { women }\end{array}$ & $\begin{array}{c}\text { Home- } \\
\text { makers }\end{array}$ & Combiners & Careerists \\
$\mathbf{0}$ & 100 & 20 & 46 & 33 \\
$\mathbf{1}$ & 100 & 25 & 52 & 24 \\
$\mathbf{2}$ & 100 & 26 & 56 & 18 \\
$\mathbf{3}$ & 100 & 38 & 50 & 12 \\
$\mathbf{4 +}$ & 100 & 63 & 35 & 3 \\
Contribution to average fertility & 100 & 36 & 50 & 14 \\
\hline
\end{tabular}

As to timing of births (Figure 3), homemakers enter motherhood earlier than women in the other groups. The combiners and particularly the careerists start their childbearing later: Whereas $25 \%$ of the homemakers have entered motherhood by the age of 22 , for combiners this percentage is reached by age 26 and for careerists by age 28 . The combiners however catch up with the homemakers, given that $50 \%$ of all women in a particular group have entered motherhood by the age of 26 (homemakers), 28 
(combiners) and 33 (careerists). On the other hand, 75\% of the homemakers enter motherhood before the age of 31 , whereas it takes until age of 35 for the same amount of combiners to have entered the motherhood.
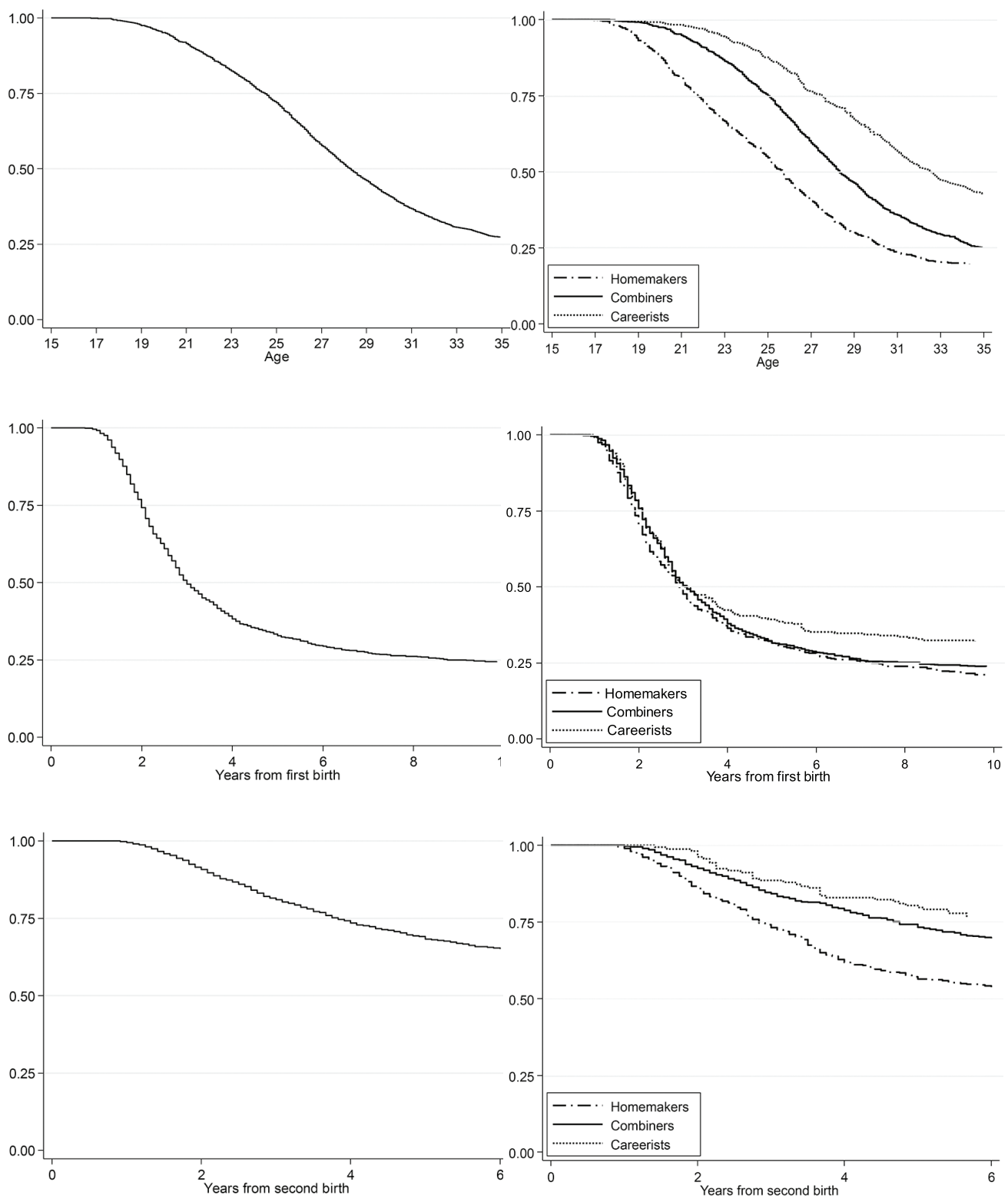

Figure 3. Transition to first, second and third parity before the age of 35 (all women and women by career strategy) 
For second births it can be observed that during the four years after the first birth, patterns are almost identical between the three groups. After four years the pattern continues identically only for the homemakers and combiners (many careerists continue to have only one child). Such similarities might indicate that even though the chosen career strategy and timing of first births as well as number of children goes hand in hand, other factors which are shared by all women influence the timing of second births. Finally, for the third births the patterns are relatively similar for the combiners and the careerists, but a larger share of the homemakers experience their third birth earlier.

\section{Characteristics of the women}

Concerning the characteristics of the women (at the age of 34) belonging to the different groups (Table 6), women with low education often end up realizing either the homemaking or combination strategies, whereas women with college education frequently realize the combination or career strategies. For example, a relatively large share of the homemakers $(26 \%)$ has low education, whereas the same is true for only $8 \%$ of the combiners and $6 \%$ of the careerists. Also, the share of college-educated homemakers is extremely low at $3 \%$, whereas $23 \%$ of the combiners and $37 \%$ of the careerists have a college education.

For activity status at the age of $34,77 \%$ of all women are in employment $-48 \%$ of homemakers in comparison to $85 \%$ of the combiners and $97 \%$ of the careerists. As far as unemployment is concerned, $21 \%$ of homemakers, $5 \%$ of the combiners, and $1 \%$ of the careerists are unemployed. The high unemployment rate among the homemakers might at least partly be explained with preferences: Some home-centered women might choose voluntary unemployment to be able to stay at home with their children after the care leave. It is likewise possible that high unemployment is a consequence of the initially preference-based decision to stay at home with the children for longer periods of time, that is, re-entry to the labour market might be difficult after long periods of inactivity. Another interpretation might be that for many homemakers, long absences from employment are related to the difficulties with establishing themselves in the labour market in the first place. The relatively large share of the homemakers enrolled in education ( $8 \%$ of the homemakers, $4 \%$ of the combiners and $1 \%$ of the careerists) in turn suggests that many women decide to gain (additional) educational qualifications after long absences from the labour market. Some homemakers for example might choose to have their children first and only thereafter enter education. Unsurprisingly, the share of inactive women is largest among the homemakers. Many homemakers receive pension $(6 \%)$ whereas almost none of the combiners and careerists do so. Furthermore, $16 \%$ of the homemakers were classified into the category "other outside the labour force" in comparison to $7 \%$ of the combiners and $1 \%$ of the careerists. Consequently, the majority of the homemakers have either no (18\%) or low income (53\%). At the other side of the spectrum are the careerists, of whom none was without income, $14 \%$ had low income, 34\% medium income, and 51\% high income. 
Finally, the data on family status shows that within all three groups, most women are married with children. The groups differ substantially, however, when it comes to the number of women without any family and the share of lone mothers: As many as $21 \%$ of the careerists do not have a family, whereas this is true for only $12 \%$ of the homemakers and $11 \%$ of the combiners. Moreover, $22 \%$ of the homemakers but only $9 \%$ of the combiners and $7 \%$ of the careerists are lone mothers. The particularly high share of lone mothers among homemakers is interesting, and suggests that the relationship between homemaking and lone motherhood should be further studied. On the one hand, longer inactive periods related to unemployment might increase the risk of divorce (Jalovaara 2001) and consequently lone parenthood. On the other hand, it is possible that there are structural incentives, which encourage homemaking of the lone mothers.

Table 6. Educational attainment, activity status, income and family status at the age of $34, \%$

\begin{tabular}{|c|c|c|c|c|}
\hline & $\begin{array}{c}\text { All } \\
\text { women }\end{array}$ & $\begin{array}{l}\text { Home- } \\
\text { makers }\end{array}$ & Combiners & Careerists \\
\hline \multicolumn{5}{|l|}{ Educational attainment } \\
\hline Low education & 13 & 26 & 8 & 6 \\
\hline General education (upper secondary level) & 6 & 8 & 6 & 5 \\
\hline Upper secondary level & 31 & 41 & 30 & 23 \\
\hline Lowest level, tertiary & 29 & 22 & 33 & 29 \\
\hline College & 20 & 3 & 23 & 37 \\
\hline \multicolumn{5}{|l|}{ Activity status } \\
\hline Employed & 77 & 48 & 85 & 97 \\
\hline Unemployed & 9 & 21 & 5 & 1 \\
\hline In education & 5 & 8 & 4 & 1 \\
\hline Pensioners & 2 & 6 & 0 & 0 \\
\hline \multicolumn{3}{|l|}{ Income } & 7 & 1 \\
\hline No income & 7 & 18 & 3 & 0 \\
\hline Low & 32 & 53 & 27 & 14 \\
\hline Medium & 34 & 23 & 41 & 34 \\
\hline High & 27 & 5 & 29 & 51 \\
\hline \multicolumn{5}{|l|}{ Family status } \\
\hline No family & 14 & 12 & 11 & 21 \\
\hline Married, no children & 4 & 3 & 4 & 7 \\
\hline Married with children & 45 & 43 & 49 & 40 \\
\hline Lone mother & 12 & 22 & 9 & 7 \\
\hline Cohabiting couple with common children & 13 & 13 & 15 & 10 \\
\hline Cohabiting couple with no common children & 2 & 2 & 2 & 1 \\
\hline Cohabiting couple without children & 8 & 4 & 9 & 14 \\
\hline
\end{tabular}




\section{Entry into motherhood}

The results from the multiple regression analysis (Table 7) show that the influence of the independent variables on entry into motherhood moves in general in the same direction within each group. Concerning education, the higher the educational level, the less likely it is that a woman has entered into the motherhood before the age of 35. The results however are statistically significant only for homemakers. Further, in all three groups, women with higher income are more likely to have had their first child during the observation period. One possible interpretation is that as the compensation for maternal and parental leaves is calculated as a percentage of the income (see discussion above), there are considerable incentives for women in each group to have children after having established their position in the labour market. Marriage is positively related to the entry into motherhood in comparison to cohabitation, although the result is naturally tentative given that the data is on family status at age of 34 . An indication of the influence of a variable running into different direction between the different groups of women is that employed women have the highest risk of entry into motherhood among the homemakers and careerists, but for all women and combiners the influence of unemployment is positive. However, the results are not statistically significant for the combiners. Finally, it is worth noticing the negative effect of inactivity on homemakers, which further supports the idea that some inactive homemakers experience problems with their physical or psychological health, which negatively influences their fertility.

As to the question on how homogeneous the group of women who have chosen the same career strategy are when it comes to the determinants of their choices, there are some differences, most notably in the case of income and marital status. For income, the differences in comparison to the reference category are particularly large between the combiners and careerists. A possible explanation is that as an employment contract at the time of maternal leave guarantees a return to the same employment position after the leave, there are particularly large incentives for the combiners and careerists to establish a good position (i.e. high income) in the labour market before having children. Further, the negative effect of cohabitation is particularly pronounced among the careerists. 
Table 7. Relative risks of the transition to motherhood, multiple regression

\begin{tabular}{|c|c|c|c|c|}
\hline & $\begin{array}{c}\text { All } \\
\text { women }\end{array}$ & $\begin{array}{l}\text { Home- } \\
\text { makers }\end{array}$ & Combiners & Careerists \\
\hline \multicolumn{5}{|l|}{ Educational attainment } \\
\hline Low education & 1 & 1 & 1 & 1 \\
\hline General education (upper secondary level) & $0.61^{* *}$ & $0.65^{\star *}$ & 0.70 & 0.84 \\
\hline Upper secondary level & $0.77^{\star *}$ & 0.83 & 0.98 & 0.87 \\
\hline Lowest level, tertiary & $0.60^{* *}$ & $0.73^{*}$ & 0.81 & 0.68 \\
\hline College & $0.48^{* *}$ & $0.57^{*}$ & 0.76 & 0.59 \\
\hline \multicolumn{5}{|l|}{ Income } \\
\hline No/low & 1 & 1 & 1 & 1 \\
\hline Medium & $1.53^{* *}$ & $1.43^{* *}$ & $1.89^{* *}$ & $2.37^{* *}$ \\
\hline High & $1.96^{* *}$ & 1.68 & $2.22^{* *}$ & $3.36^{* *}$ \\
\hline \multicolumn{5}{|l|}{ Activity status } \\
\hline Employed & 1 & 1 & 1 & 1 \\
\hline Unemployed & $1.29^{* *}$ & 0.91 & 1.05 & 0.39 \\
\hline In education & $0.51^{* *}$ & $0.40^{* *}$ & $0.53^{* *}$ & 0.79 \\
\hline Inactive & 0.88 & $0.57^{* *}$ & 0.83 & 0.00 \\
\hline \multicolumn{5}{|l|}{ Family status at $34^{2}$} \\
\hline Married & 1 & 1 & 1 & 1 \\
\hline Cohabiting & $0.51^{* *}$ & 0.80 & $0.51^{* *}$ & $0.33^{* *}$ \\
\hline At risk & 2243 & 637 & 1129 & 477 \\
\hline Failures & 1633 & 512 & 847 & 274 \\
\hline -Log Likelihood & 11469 & 2943 & 5317 & 1496 \\
\hline
\end{tabular}

Notes: p-values smaller than 0.05 and 0.01 are indicated with one and two stars respectively.

${ }^{1}$ Inactive $=$ "pensioners" and "others outside the labour force". ${ }^{2}$ Married = "married, no children" and "married, with children". "Cohabiting" = "cohabiting couple with common children", "cohabiting couple with no common children" and "cohabiting couples without children".

\section{Discussion}

The purpose of the article was to study women's heterogeneous career strategies and to provide descriptive evidence of the characteristics, as well as the level and timing, of fertility and entry into motherhood among women belonging to different career strategy groups. To my knowledge, the current study is the first to examine the time Finnish women have spent in different activities over a longer time period and to correlate the time spent in different activities with the level and timing of fertility.

The study shows that Finnish women's career strategies are indeed heterogeneous, and that a substantial share of women can be found in each of the three career strategy groups. 
Moreover, there is a strong correlation between longitudinal labour market careers and fertility; long absences from employment often go together with large family size and relatively young age at entry into motherhood, whereas continuous employment, higher age at entry into motherhood, and childlessness/low fertility are important correlates. The results are encouraging, as they suggest that study on heterogeneity increases our understanding of women's fertility patterns. Moreover, in the light of the theoretical framework applied in this article, the results can be interpreted as confirmatory evidence for joint decision-making concerning childbearing and employment.

However, it is important to bear in mind that the study did not investigate the actual relationship between preferences, constraints, and choices, which means that the results are open to other kinds of theoretical explanations as well. Indeed, the classification is based on activity status and therefore cannot elucidate details on women's preferences or voluntary and involuntary career choices but investigates only the realized career path. For example, long periods of unemployment after childbirth might indicate difficulties in re-entering the labour market, but could at the same time signal homecentered preferences. Furthermore, re-entering the labour market might be difficult due to an initially preference-based decision to stay at home for child rearing. Thus, more research is needed to understand why different kinds of relationships between work and family can be observed in the data.

It is also worth emphasizing that the results are still tentative. Childbearing continues past the age of 35, which means that the results found here are to some extent likely to reflect the differences in the timing of births. For example, many women who started their childbearing later might have children even after the age of 35. In future studies, women's career and family choices should be studied throughout their reproductive years. Moreover, the particularly high share of childless homemakers indicates that the career strategy categories need to be refined to give a more nuanced picture of women's choices and constraints. Cluster analysis might, for instance, be a suitable technique to approach the matter. Further, the fact that the study cohort experienced the 1990s recession in their early 20 s might have profoundly influenced their career choices. It is thus not certain how representative the 1969-cohort is of all Finnish women. It is for example possible that the combination of the generous rules for the home care allowance and high unemployment rate, or high unemployment rate alone, influenced the labour force participation and attachment of these women particularly negatively. This in turn suggests that the role of labour market conditions and regulations should be considered more profoundly within the theoretical framework.

Despite the difficulties mentioned above, some general comments can be made about the implications of the results. Firstly, the Finnish research (e.g. Kosonen 2011; LammiTaskula 2004) and public discussion (Helsingin Sanomat 2012; Taloussanomat 2012) on the home care allowance has tended to concentrate on its influence on women's labour market participation. However, the results of this study suggest that those mothers who 
stay outside the labour market for longer periods of time also experience higher levels of fertility. Thus, more attention should be given to the ways in which the allowance might promote larger families.

Secondly, in international comparisons, Finland is found to have a relatively high level of childlessness (Andersson et al. 2009). The current study indicates that the reasons for childlessness are complex. On the one extreme there is a substantial amount of women with a loose connection to the labour market and low income. On the other extreme there are women with continuous labour market and education careers with relatively high educational qualifications. Further research to explore this link would be needed.

Thirdly, as to the cross-country comparative theoretical discussions on low fertility, the results suggest that the high share of homemakers and their high fertility require more attention. As discussed in the introductory section of this paper, several theories on low fertility emphasize the role of women-friendly family policy as a facilitator of role compatibility. Thus, the concentration has automatically been on the adaptive and work-centred women (and on combiners and careerists). Yet according to this study, even in Finland, where family policy supports the combination of work and family, homemakers constitute a substantially large group that contributes to the overall fertility more than its share of the population. This conclusion stands despite the fact that in the current study e.g. many childless women and pensioners were classified as homemakers, even though the reason for their homemaking is most likely not related to their choices or preferences concerning work and children.

Consequently, there should be more focus on the size and importance of female homemakers for fertility. Indeed, to better understand cross-country differences in fertility as well as differences in cohort fertility over time, it is necessary to look at the behaviour of all women. It is, for example, well known that there have been major changes in women's labour market participation during the past decades and that women's labour market participation and part-time work are more common in certain countries than in others (e.g. OECD 2012). Consequently, it is safe to assume that the share of the homemakers, combiners, and careerists varies between the different countries and cohorts. Thus, the cross-country and cross-cohort differences in fertility can and should be traced back to the choices women make about their career strategies, as well as to the relative proportion of women making these choices.

\section{Acknowledgements}

This paper is a revised version of a chapter in my dissertation at Heidelberg University. I would like to thank Statistics Finland for providing me with the data for analysis (permission TK53-637-10), the two anonymous referees for their constructive feedback, my supervisor Uwe Wagschal for his comments on the earlier versions of this paper and Lena Münke for language correction. 


\section{References}

Andersson, Gunnar. 2004. Childbearing after migration: Fertility patterns of foreignborn women in Sweden. International Migration Review 38(2): 747-775.

Andersson, Gunnar, Marit Rönsen, Lisbeth B. Knudsen, Trude Lappegård, Gerda Neyer and Kari Skrede. 2009. Cohort fertility patterns in the Nordic countries. Demographic Research 20: 313-352.

Anttonen, Anneli. 2003. Lastenhoidon kaksi maailmaa. In: Perhe murroksessa Kriittisen perhetutkimuksen jäljillä, edited by Hannele Forsberg and Ritva Nätkin. Helsinki: Gaudeamus.

Becker, Gary S. 1981/1991. A treatise on the family. Cambridge, MA: Harvard University Press.

Bernhardt, Eva M. 2000. Female careers between employment and children. Paper presented at the seminar: Low fertility, families and public policies. Organized by the European Observatory on Family Matters in Sevilla, September 15.-16. 2000.

Box-Steffensmeier, Janet M., Jan Reiter and Christoph Zorn. 2003. Nonproportional hazards and event history analysis in international relations. Journal of Conflict Resolution 47(1): 33-53.

Brewster, Karin L. and Ronald R. Rindfuss. 2000. Fertility and women's employment in industrialized nations. Annual Review of Sociology 26: 271-296.

Cooke, Lynn Prince. 2004. The gendered division of labour and family outcomes in Germany. Journal of Marriage and Family 66: 1246-1259.

Esping-Andersen, Gøsta. 1999. The household economy. In: Social Foundations of Postindustrial Economies, by Gøsta Esping-Andersen, pp. 47-72. Oxford: Oxford University Press.

Eurostat. 2013. [online]. New Cronos Database. [Accessed in March 2013], available from: http://epp.eurostat.ec.europa.eu.

Frejka, Tomas. 2008. Overview Chapter 2: Parity distribution and completed family size in Europe: Incipient decline of the two-child family model? Demographic Research 19: 47-72.

Goldstein, Joshua, Wolfgang Lutz and Maria Rita Testa. 2003. The emergence of subreplacement family size ideals in Europe. Population Research and Policy Review 22(5-6): 479-496.

Haataja, Anita. 2005. Äidit ja isät työmarkkinoilla 1989-2002/2003. Sosiaali- ja terveysministeriön selvityksiä 2005:29.

---. 2007. Suomalainen äitiys-, isyys ja vanhempainrahajärjestelmä: ylistämisestä alistamiseen? In: Työn ja perheen tasapaino: sääntelyä, tutkimusta ja kehittämistä, edited by Anna-Maija Castrén, pp. 14-37, Helsinki: Helsingin Yliopistopaino.

Haataja, Anita and Elina Pylkkänen. 2009. Verotus ja sukupuolten välinen tasa-arvo. In: Oikeudenmukainen verotus - mistä rahat yhteiseen hyvinvointiin?, edited by Antti Alaja, pp. 143-167, Kalevi Sorsa säätiön julkaisuja 2/2009.

Hakim, Catherine. 1998. Developing a sociology for the twenty-first Century: Preference theory. The British Journal of Sociology 49(1): 137-143.

---. 2000. Work-lifestyle choices in the $21^{\text {st }}$ Century: Preference theory. Oxford: Oxford University Press. 
---. 2002. Lifestyle preferences as determinants of women's differentiated labour market careers. Work and Occupations 29(4): 428-459.

---. 2003a. A new approach to explaining fertility patterns: Preference theory. Population and Development Review 29(3): 349-374.

---. 2003b. Models of the family in modern societies: Ideals and realities. Aldershot: Ashgate.

Hakovirta, Mia and Milla Salin. 2006. Valinta vai pakko? Kansainvälinen vertailu äitien preferoiman ja toteutuneen työmarkkina-aseman yhteydestä. Janus 14(3): 255-271.

Hämäläinen, Ulla and Pentti Takala. 2007. Isien perhevapaat ja tasa-arvo. In: Perhevapaavalinnat ja perhevapaiden kustannukset sukupuolten välisen tasa-arvon jarruina työelämässä?, edited by Reija Lilja, Rita Asplund and Kaisa Kauppinen, pp. 22-45, Sosiaali- ja terveysministeriön selvityksiä 2007:69.

Heiland, Frank, Alexia Prskawetz and Warren C. Sanderson. 2008. Are individuals' desired family sizes stable? Evidence from West German panel data. European Journal of Population 24: 129-156.

Helsingin Sanomat. 2012. [online]. Katainen haluaa kotiäidit töihin. Published on 12.11.2012. Available from: http://www.hs.fi/politiikka/Katainen+haluaa+koti\%C3\%A4idit+t\%C3\%B6ihin/a1305614781487

Hiilamo, Heikki. 2000. Perhepolitiikka mikrotasolla 1991-1999. Yhteiskuntapolitiikka 65(6): 502-519.

Human Fertility Database. 2012. [online]. Max Planck Institute for Demographic Research (Germany) and Vienna Institute of Demography (Austria). [Accessed in March 2013] Available from: www.humanfertility.org.

Jalovaara, Marika. 2001. Socio-economic status and divorce in first marriages in Finland 1991-93. Population Studies 55: 119-133.

Janus, Alexander L. 2012. The gap between mothers' work-family orientations and employment trajectories in 18 OECD Countries. European Sociological Review.

Kan, Man Yee. 2007. Work orientation and wives' employment careers: An evaluation of Hakim's preference theory. Work and Occupations 34(4): 430-462.

Kangas, Olli and Tine Rostgaard. 2007. Preferences or institutions? Work family life opportunities in seven European countries. Journal of European Social Policy 17(3): 240-256.

Kosonen, Tuomas. 2011. The effect of child-care subsidies on the labour supply of parents. In: Encouragement and discouragement Essays on taxation and government expenditure, by Tuomas Kosonen, Government Institute for Economic Research, Publications 57.

Kurjenoja, Jaana. 2003. Lapsiperheiden verokurimus Lapsiperheiden verotus, lapsilisät sekä päivähoito 11 Euroopan maassa. Verotietoa 37.

Lewis, Jane, Mary Campbell and Carmen Huerta. 2008. Patterns of paid and unpaid work in Western Europe: Gender, commodification, preferences and the implications for policy. Journal of European Social Policy 18(1): 21-37.

Lammi-Taskula, Johanna. 2004. Äidit työmarkkinoilla - kahden kerroksen väkeä?. Yhteiskuntapolitiikka 69(2): 202-206.

---. 2008. Doing fatherhood: Understanding the gendered use of parental leave in Finland. Fathering 6(2): 133-148. 
McDonald, Peter. 2000a. Gender equity, social institutions and the future of fertility. Journal of Population Research 17(1): 1-16.

---. 2000b. Gender equity in theories of fertility transition. Population and Development Review 26(3): 427-439.

---. 2002. Sustaining fertility through public policy: The range of options. Population, English Edition 57(3): 417-446.

Miettinen, Anneli. 2011. Population data on Finland 1900-2010. Finnish Yearbook of Population Research 2011: 163-172.

Miettunen, Laura. 2008. Lasten kotihoidon tuen kuntalisät osana suomalaista päivähoitojärjestelmää. Sosiaali-ja terveysturvan tutkimuksia 101. Helsinki: Kelan tutkimusosasto.

Myrskylä, Pekka. 2010. Taantuma ja työttömyys. Työ- ja elinkeinoministeriön julkaisuja: Työ ja yrittäjyys 57/2010.

OECD. 2001. Employment Outlook 2001. OECD Publications.

---. 2012. [online]. Family database. OECD, Paris, Available from: www.oecd.org/ social/family/database.

---. 2013. [online]. Labour force statistics. Available from: http://stats.oecd.org/.

Pitkänen, Kari and Marika Jalovaara. 2007. Perheet ja perheenmuodostus. In: Suomen $v \ddot{a} e s t o ̈$, edited by Seppo Koskinen, Tuija Martelin, Irma-Leena Notkola, Veijo Notkola and Kari Pitkänen, Helsinki: Gaudeamus.

Rindfuss, Ronald R. and Karin L. Brewster. 1996. Childrearing and fertility. Population and Development Review 22: S258-S289.

Rindfuss, Ronald R., Karen Benjamin Guzzo and Philip S. Morgan. 2003. The changing institutional context of low fertility. Population Research and Policy Review 22: 411-438.

Ruokolainen, Anne and Irma-Leena Notkola. 2007. Hedelmällisyys. In: Suomen väestö, edited by Seppo Koskinen, Tuija Martelin, Irma-Leena Notkola, Veijo Notkola and Kari Pitkänen, Helsinki: Gaudeamus.

Salmi, Minna and Johanna Lammi-Taskula. 2002. Mitä pienten lasten vanhemmat haluavat perhepolitiikalta? Yhteiskuntapolitiikka 67(6): 578-583.

Salmi, Minna, Johanna Lammi-Taskula and Johanna Närvi. 2009. Perhevapaat ja naisten osallistuminen työelämään. In: Perhevapaat ja työelämän tasa-arvo, edited by Minna Salmi, Johanna Lammi-Taskula and Johanna Närvi, pp. 32-43, Työ- ja elinkeinoministeriön julkaisuja 24/2009.

Schleutker, Elina. (in press). Fertility, family policy and welfare regimes. Comparative Population Studies - Zeitschrift für Bevölkerungswissenschaft.

Sobotka, Tomáś. 2004. Is lowest-low fertility in Europe explained by the postponement of childbearing?. Population and Development Review 30(2): 195-220.

Statistics Finland. 2011. An extract from the Finnish longitudinal register data, provided by Statistics Finland (permission TK53-637-10).

---. 2013. Families. [online]. ISSN=1798-3231.2011, Appendix table 4. Reconstituted families 1990-2011. Helsinki: Statistics Finland [Accessed in March 2013]. Available from: http://tilastokeskus.fi/til/perh/2011/perh_2011_2012-05-25 tau 004 en.html. 
Takala, Pentti. 2000. Lastenhoito ja sen julkinen tuki. Helsinki: Stakes/Kela.

---. 2005. Uuden isyysvapaan ja isän muiden perhevapaiden käyttö. Sosiaali- ja terveysturvan selosteita 43/2005.

Taloussanomat. 2012. [online]. Vartiainen pyytää anteeksi kotihoidon kutsumista velttoiluksi. Published on 18.5.2013. Available from: http://www.taloussanomat. fi/kotimaa/2012/05/18/vartiainen-pyytaa-anteeksi-kotihoidon-kutsumistavelttoiluksi/201229689/12.

Thévenon, Olivier. 2011. Family policies in OECD Countries: A comparative analysis. Population and Development Review 37(1): 57-87.

Torr, Berna Miller and Susan E. Short. 2004. Second births and the second shift: A research note on gender equity and fertility. Population and Development Review 30(1): 109-130.

Välimäki, Anna-Leena and Pirkko-Liisa Rauhala. 2000. Lasten päivähoidon taipuminen yhteiskunnallisiin murroksiin Suomessa. Yhteiskuntapolitiikka 65(5): 387-405.

van de Kaa, Dirk J. 1987. Europe's second demographic transition. Population Bulletin 42(1).

---, Dirk J. 2001. Postmodern fertility preferences: From changing value orientation to new behaviour. Population and Development Review (27): S290-S331.

Vikat, Andres. 2002. Fertility in Finland in the 1980s and 1990s: Analysis of fertility trend by age and parity. Yearbook of Population Research in Finland 38: 159-178.

---. 2004. Women's labour force attachment and childbearing in Finland. Demographic Research, special collection 3.

Vitali, Agnese, Francesco C. Billari, Alexia Prskawetz and Maria Rita Testa. 2009. Preference theory and low fertility: A comparative perspective. European Journal of Population 25(4): 413-438. 